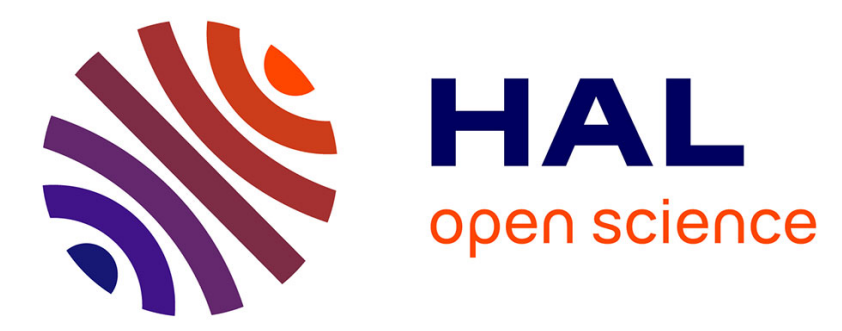

\title{
Negative resistance effects with Josephson junctions H. Kanter
}

\section{To cite this version:}

H. Kanter. Negative resistance effects with Josephson junctions. Revue de Physique Appliquée, 1974, 9 (1), pp.227-227. 10.1051/rphysap:0197400901022700 . jpa-00243744

\section{HAL Id: jpa-00243744 https://hal.science/jpa-00243744}

Submitted on 1 Jan 1974

HAL is a multi-disciplinary open access archive for the deposit and dissemination of scientific research documents, whether they are published or not. The documents may come from teaching and research institutions in France or abroad, or from public or private research centers.
L'archive ouverte pluridisciplinaire HAL, est destinée au dépôt et à la diffusion de documents scientifiques de niveau recherche, publiés ou non, émanant des établissements d'enseignement et de recherche français ou étrangers, des laboratoires publics ou privés. 


\title{
NEGATIVE RESISTANCE EFFECTS WITH JOSEPHSON JUNCTIONS (*)
}

\author{
H. KANTER \\ Electronics Research Laboratory, The Aerospace Corporation \\ El Segundo, California 90009, USA
}

\begin{abstract}
Résumé. - On peut obtenir, avec une jonction Josephson, une résistance négative et les effets qui en découlent de la même manière qu'avec une diode Varactor. La fréquence de pompe est alors fournie par la jonction qui n'est plus polarisée que par une source continue. Un autre effet de résistance négative, caractéristique des jonctions Josephson, est possible ; il a été prédit dans le cas d'un montage comportant une jonction shuntée par une faible résistance et polarisée par un courant. Cet effet a été récemment mis en évidence à $9 \mathrm{GHz}$. La fréquence (Josephson) de pompe est alors plus petite que celle du signal et le phénomène peut être obtenu sur une large bande de fréquence. (Dans un amplificateur paramétrique classique, la fréquence de pompe est supérieure à la fréquence signal et à la fréquence "idler » et la bande de fréquence est étroite.)

La large bande de fréquence rend le dispositif insensible aux fluctuations de l'accord ou du courant de polarisation et par ailleurs, la faible impédance de la jonction facilite le problème d'adaptation généralement rencontré. Les performances comparées d'un tel dispositif utilisé en hyperfréquences sont données.
\end{abstract}

Abstract. - Conventional negative resistance effects can be generated with a Josephson junction quite similar to that obtained with Varactor diodes, with the additional advantage that the internal, self-generated oscillations serve as a pump, i. e., only a dc source is needed instead of a high frequency pump source. However, another negative resistance effect typical for a Josephson junction is possible as has been predicted recently for the current controlled, highly damped junction model. The effect has recently been demonstrated experimentally at $9 \mathrm{GHz}$. Characteristically, the pump (Josephson) frequency is smaller than the frequency of the amplified signal and the pump mechanism is effective over a broad range of frequencies in contrast to the conventional parametric negative resistance effect where the pump frequency exceeds that of the signal and idler and where the frequency of operation is limited to a narrow range. The broad-band feature renders the amplifier operation uncritical to tuning and bias voltage fluctuations. The fact that the junction is the element of lowest impedance in the circuit alleviates to a degree the matching problem generally encountered with Josephson contacts. An assessment of the competitiveness of this effect in microwave technology is given.

See also Appl. Phys. Lett. 23 (1973) 350.

$\left(^{*}\right)$ This work was supported by the US Air Force under Contract \# F 04701-72-C 0073. 